\title{
PYROXENES AND THE P-T PATH IN GRANULITE FACIES OF SW MINAS GERAIS, BRAZIL
}

\author{
ASIT CHOUDHURI*, SUNDARAM S. IYER**, JOSÉ RENATO NOGUEIRA*
}

\begin{abstract}
RESUMO PIROXENOS E O PERCURSO P-T EM FÁCIES GRANULITO DO SW DE MINAS GERAIS, BRASIL Piroxênios de fácies granulito do Maciço de Guaxupé apresentam exsoluções características na forma de lamelas paralelas a (001) em clinopiroxênios cálcicos e, por vezes, na forma de três grupos de lamelas paralelas a. (001) - lamela relativamente espessa, b. (100) - lamela fina, c. -(001) lamela muito fina. A lamela espessa (001) representa pigeonita, posteriormente convertida para ortopiroxênio. Composicionalmente, os piroxênios são muito ricos em ferro, e o $K D{ }^{\mathrm{OPX}-\mathrm{CPX}}=0,65$ se encaixa dentro da gama de variação dos piroxênios metamórficos. Estes piroxênios se equilibraram em condições de fácies granulito sob temperaturas estimadas entre $786^{\circ} \mathrm{C}$ e $833^{\circ} \mathrm{C}$, o que está de acordo com estimativas anteriores feitas para o terreno granulítico de Guaxupé. O resfriamento a partir destas temperaturas produziu as texturas de exsolução observadas. Considerando que as condições para o equilíbrio dos piroxênios coincide com as temperaturas de pico metamórfico, é possível que estes tenham se resfriado ao longo de um caminho P-T-t de descompressão isotérmica estabelecido para os granulitos de Guaxupé.
\end{abstract}

Palavras- chave: piroxênios. granulitos, exsolução

\begin{abstract}
Granulite facies pyroxenes from the Guaxupé Massif show characteristic exsolution in the form of lamellae parallel with $(001)$ in calcic clinopyroxenes.and at times three sets of lamellae parallel with a. (001) -relatively broad lamellae , b. (100) - fine lamellae, and c. (001) - very fine lamellae. The broad (001) lamellae represent pigeonite, later inverted to orthopyroxene.Compositionally, the pyroxenes are very iron-rich, and $K D{ }^{\mathrm{OPX}-\mathrm{CPX}}$ $=0.65$ is within the range for metamorphic pyroxenes. These pyroxenes equilibrated in granulite facies yield temperature estimates of $786^{\circ} \mathrm{C}$ to $833^{\circ} \mathrm{C}$, which is in keeping with previous estimates for the Guaxupé granulite terrain. Cooling from these temperatures resulted in the observed exsolutions. Since the conditions for the equilibration of the pyroxenes coincide with peak metamorphic temperatures, it is possible that they cooled along the isothermal decompression (ITD) path established for the Guaxupe granulites.

Keywords: pyroxenes, granulites, exsolution
\end{abstract}

INTRODUCTION Exsolution of pyroxenes, both igneous and metamorphic, is a common feature in rocks that have cooled slowly from higher temperatures. The exsolution takes the form of simple to complex lamellae in igneous rocks in the form of blebs as well, that generally follow the (100) or (001) orientations, depending on the pyroxene (Deer et al 1992). In the case of metamorphic rocks, granulite facies pyroxenes often contain exsolution lamellae that have resulted owing to cooling subsequent to peak metamorphic temperatures. Integrated total analysis of such pyroxenes have yielded compositions either related to their pre-metamorphic igneous history or to the high temperature granulite event itself (Bohlen and Essene, 1978; Sandiford and Powell, 1986). In the latter case, temperatures should be close to maximum values prior to cooling and exsolution, and this exsolution provides insight into the nature of crystallographic transformations in the pyroxenes.

In the granulite facies terrain that covers the area extending from São Paulo to Minas Gerais State coexisting orthopyroxene and clinopyroxene have been studied and analysed for geothermometry (Oliveira, 1978; Santos, 1987), and exsolution in mangerite pyroxenes have been reported from the Caldas Massif further to the south( Janasi, 1995). Within the framework of a broader study of the Guaxupe granuiite terrain, a closer examination of pyroxenes, mainly from a charnockite-mangerite suite, reveals interesting details with respect to their cooling from peak metamorphic temperatures. Bearing in mind the importance of pyroxenes in the granulite facies, the petrography of coexisting orthopyroxene and calcic clinopyroxene from this region in SW Minas Gerais are reported here, and the temperature for their equilibration is estimated based on the method of Wood and Banno (1973).

HOST ROCKS OF PYROXENES The Guaxupé high grade terrain (Guaxupé Massif or Guaxupé Nappe, or
Socorro-Guaxupé Nappe) belongs to the Varginha-Guaxupé Complex of Cavalcante et al. (1979), stretching to the east and southeast of Guaxupé town, as well as to the south (Fig. $1)$. The high-grade rocks consist of charnockitic gneisses, with compositions varying from charnockite to mangerite, enderbitic gneisses, mafic granulites and garnet-biotite gneisses, with or without sillimanite.The rocks of the charnockite suite contain mesoperthite, quartz, plagioclase, orthoand clinopyroxenes, rare dark green amphibole - probably hornblende, and biotite; accessory minerals are well-formed zircon, apatite, in one case garnet, and as yet unidentified opaques.Field and textural features of these rocks suggest their syntectonic emplacement in the granulite facies under water-deficient conditions (Choudhuri et al. , 1995). As in other granulite terrains, it is possible that here also the fluids accompanying granulite facies metamorphism contained $\mathrm{CO}_{2}$ , but so far high-density $\mathrm{CO}_{2}$ fluids corresponding to the peak P-T have not been found. However, fluid-absent melting (dehydration melting), is possibly the main process of granulite formation in this region, with $\mathrm{H}_{2} \mathrm{O}$ internally buffered, and without the need of an external source of $\mathrm{CO}_{2}$ (Bhattacharya and Sen, 1986). These details are yet to be investigated by fluid inclusion study. The host rocks of the pyroxenes of this study are gneisses of the charnockitemangerite suite, one mafic enderbite and one mafic granulite.The exsolution textures described below are from pyroxenes of the charnockite-mangerite suite.

PETROGRAPHY AND COMPOSITION OF PYROXENES In the charnockite gneisses, both ortho-and clinopyroxenes are very strongly coloured, the former being pleochroic from greenish to buff, and the latter a distinct non-pleochroic deep green. The pyroxenes have irregular shapes and occur as trails parallel to the gneissic foliation of the host rocks. Orthopyroxenes contain very fine (100) exso-

* Institute de Geociências, Universidade Estadual de Campinas, Caixa Postal 6152, 13081-970, Campinas, SP, Brazil.

** Institute of Physics and Astronomy, University of Calgary, Canada. 


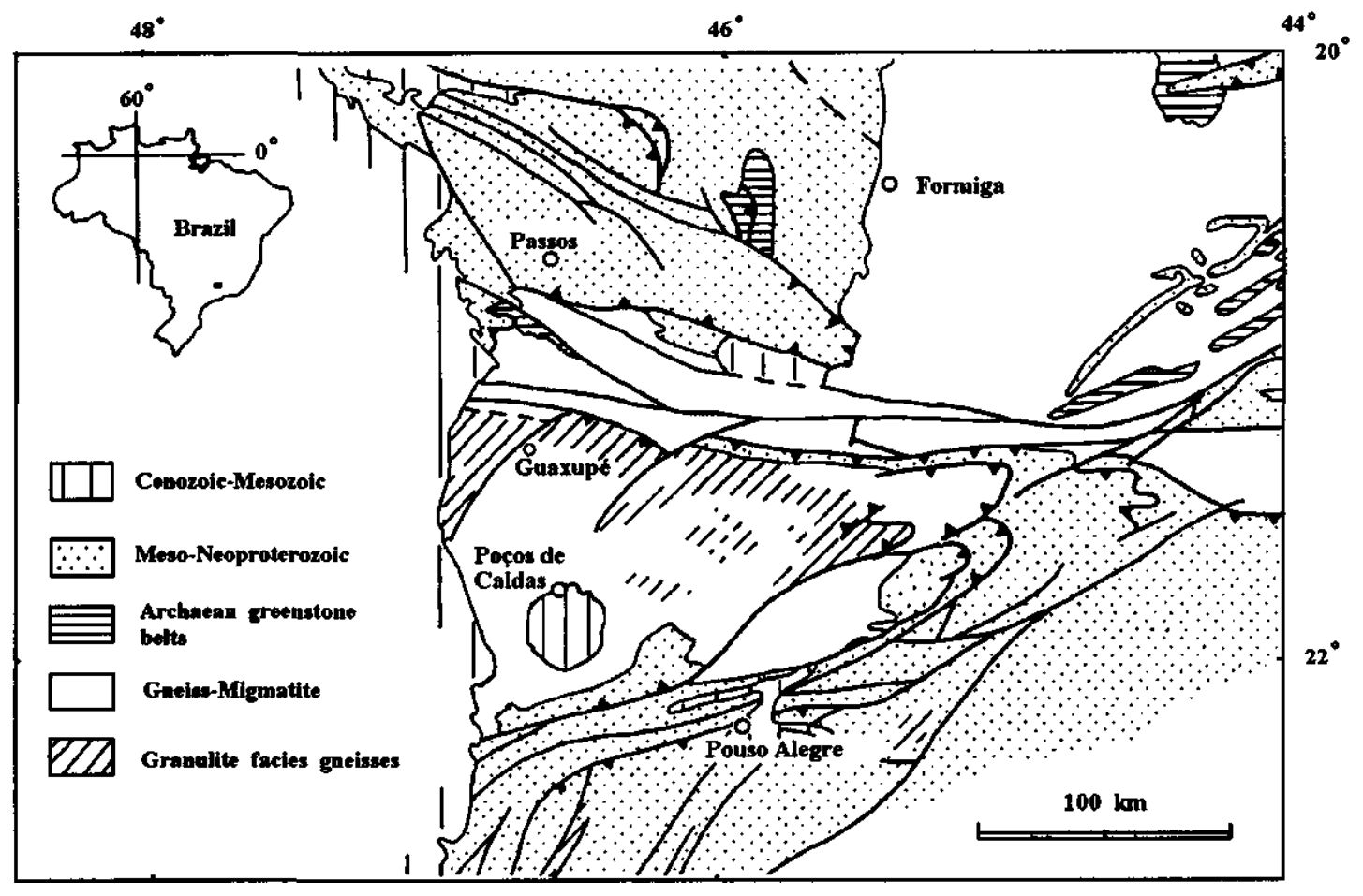

Figure 1 - Simplified geological map of SW Minas Gerais State with main rock units around the high grade granulite terrain of Guaxupé, after Schobbenhaus et al. (1984).

Figura 1 - Mapa geológico simplificado do sudoeste do Estado de Minas Gerais com as principals unidades litológicas na área do terreno granulítico de alto grau de Guaxupé, segundo Schobbenhaus et al. (1984).

lution of clinopyroxene lamellae, and host and lamellae can be easily distinguished by their interference colours and extinction. Most clinopyroxenes have exsolution lamellae of inverted pigeonite parallel to (001), though some of them show a set of complex exsolutions. In these, the (001) exsolution lamellae are more prominent, with much finer (100) lamellae in between, and, at times, a second set of very fine (001) lamellae (Fig. 2). The main (001) lamellae are only 5um or less in width, whereas the (100) and second (001) are on the order of lum.This is in contrast to the broad exsolution found in igneous rocks - relict igneous calcic clinopyroxenes with (100) exsolution of orthopyroxene have been observed in a granulite facies metagabbro from the environs of Gua-
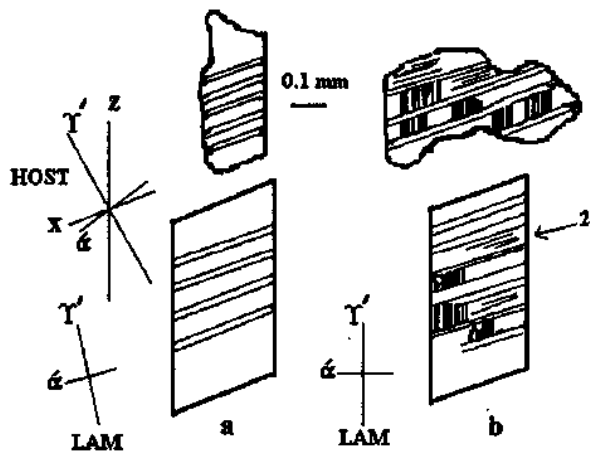
xupe.

Curiously, some samples of the rocks studied here contain Figure 2 - Exsolution in calcic clinopyroxenes seen on near calcic clinopyroxene in which both host and exsolution la- 1010$)$ sections with approximate orientation for host and unin verted pigeonite.The approximate orientation of host and lamellae (LAM); in the second clinopyroxene, there are three lamellae are shown in Fig. 1.From examples given by Ollila exsolutions - (001), (100) and a second set of (001) marked 2. et al. (1988), it can be conjectured that in the case of calcic Irregular outlines are pyroxenes as seen in thin section, and clinopyroxene with complex lamellae, pigeonite lamellae ex-below these are schematic sections with optic orientations solved along (001) and then inverted to orthopyroxene, after indicated.

which the host further exsolved orthopyroxene along (100) Figura 2 - Exsoluções em piroxênios cálcicos vistas em seções próximas a and (001).All these lamellae are too fine for analysis, and in (010) com orientação aproximada do mineral encaixante (host) e das lamelas consequence temperature estimates are based on integrated (LAM); no segundo clinopiroxênio ocorrem três exsoluções - (001), (100), e analyses. uma segunda (001) indicado com 2. Contornos iregulares São de piroxênios

As would be expected from their strong colours, the em lâminas, e em baixo São seções esquemáticas com orientações ópticas pyroxenes are unusually iron-rich. The $\mathrm{FeO}$ content of the indicadas.

orthopyroxenes varies from 42 to $48 \%$, and of the Ca-clino-ing fayalite, for which there is no indication in the rocks pyroxene from 25 to $28 \%$; their $\mathrm{Mg} / \mathrm{Mg}+\mathrm{Fe}$ ratios are in studied here. The compositions of the pyroxenes are given in the range 0.21 to 0.06 . This is most likely due to their iron-Table 1 , and are compared with those of Lofoten in the rich host rocks (compositions of the host rocks are given by pyroxene quadrilateral in Fig. 3. In this figure, the range of lyer et al (1996) with corresponding sample numbers). In compositions of pyroxenes from São Jose do Rio Pardo (Olithis respect they are very similar to pyroxenes from the veira and Hypolito, 1978) and Guaranesia (Santos, 1988), mangerite-charnockite suite of Lofoten, Norway (Ormaasen, both localities from the Varginha-Guaxupé Complex, but 1977). The latter have, however, formed by reactions involv- 
Table 1, Pyroxene analyses from granulites of Guaxupé, Brazil.

Tabela 1. Análises de piroxênios de granulitos de Guaxupé, Brasil.

\begin{tabular}{|c|c|c|c|c|c|c|c|c|c|c|c|c|}
\hline & \multicolumn{2}{|c|}{ AC 7/16 } & \multicolumn{2}{|c|}{ AC 6/17 } & \multicolumn{2}{|c|}{ AC 6/14 } & \multicolumn{2}{|c|}{ AC 13/15 } & \multicolumn{4}{|c|}{ AC 89} \\
\hline & \multirow{2}{*}{ Opx } & \multirow{2}{*}{ Cpx } & \multirow{2}{*}{ Opx } & \multirow{2}{*}{ Cpx } & \multirow{2}{*}{ Opx } & \multirow{2}{*}{ Cpx } & \multirow{2}{*}{$O p x$} & \multirow{2}{*}{ Cpx } & \multicolumn{2}{|c|}{ Opx } & \multicolumn{2}{|c|}{ Cpx } \\
\hline & & & & & & & & & core & rim & core & rim \\
\hline $\mathrm{SiO}_{2}$ & 47.1 & 48.9 & 46.4 & 48.8 & 47.2 & 48.8 & 46.4 & 48.3 & 49.81 & 50.35 & 50.31 & 51,05 \\
\hline $\mathrm{TiO}_{2}$ & 0.05 & 0.11 & 0.14 & 0.15 & 0.09 & 0.15 & 0.10 & 0.13 & 0.07 & 0.03 & 0,15 & 0,12 \\
\hline $\mathbf{A l}_{2} \mathbf{O}_{3}$ & 0.37 & 0.91 & 0.28 & 0.94 & 0.48 & 1.21 & 0.30 & 1.01 & 1.54 & 1,14 & 2,79 & 1,92 \\
\hline $\mathrm{FeO}^{*}$ & 42.0 & 25.3 & 47.6 & 29.0 & 45.2 & 25.1 & 48.6 & 28.3 & 33.32 & 30,81 & 15,7 & 13,91 \\
\hline MnO & 2.25 & 1.27 & 1.83 & 0.92 & 1.59 & 0.77 & 1.68 & 0.80 & 0.42 & 0,39 & 0,17 & 0,14 \\
\hline $\mathrm{MgO}$ & 3.96 & 3.44 & 2.25 & 2.07 & 4.40 & 4.88 & 1.94 & 1.74 & 15.25 & 16,83 & 10,28 & 11,58 \\
\hline $\mathrm{CaO}$ & 3.49 & 19.5 & 0.80 & 17.8 & 0.87 & 19.5 & 0.76 & 19.4 & 1.63 & 0,82 & 20,75 & 21,58 \\
\hline $\mathrm{Na}_{2} \mathrm{O}$ & 0.07 & 0.43 & - & 0.51 & - & 0.55 & - & 0.53 & - & - & 0,33 & 0,34 \\
\hline Sum & 99.49 & 99.86 & 99.47 & 99.69 & 99.92 & 99.96 & 100.0 & 100.3 & 102.04 & 100.37 & 100.48 & 100.64 \\
\hline Si & 1.990 & 1.980 & 2.000 & 1.980 & 1.990 & 1.970 & 2.000 & 1.970 & 1.926 & 1.951 & 1.924 & 1.937 \\
\hline $\mathbf{A l}^{\mathrm{jv}}$ & 0.010 & 0.020 & - & 0.020 & 0.001 & 0.030 & - & 0.020 & 0.070 & 0,049 & 0,076 & 0,063 \\
\hline$A l^{v i}$ & 0.009 & 0.023 & 0.014 & 0.025 & 0.024 & 0.028 & 0.015 & 0.018 & - & 0,03 & 0,05 & 0,023 \\
\hline Ti & 0.002 & 0.003 & 0.005 & 0.005 & 0.003 & 0.005 & 0.003 & 0.004 & 0,002 & 0,001 & 0,004 & 0,003 \\
\hline $\mathrm{Fe}^{2+}$ & 1.490 & 0.856 & 1.72 & 0.995 & 1.600 & 0.846 & 1.750 & 0.966 & 1,078 & 0,999 & 0,502 & 0,441 \\
\hline Mn & 0.081 & 0.043 & 0.047 & 0.032 & 0.057 & 0.026 & 0.061 & 0.028 & 0,014 & 0,013 & 0,006 & 0,004 \\
\hline $\mathbf{M g}$ & 0.250 & 0.207 & 0.145 & 0.127 & 0.277 & 0.233 & 0.125 & 0.106 & 0,879 & 0,972 & 0,586 & 0,655 \\
\hline $\mathrm{Ca}$ & 0.158 & 0.846 & 0.005 & 0.784 & 0.039 & 0.842 & 0.008 & 0.847 & 0,068 & 0,034 & 0,85 & 0,877 \\
\hline $\mathrm{Na}$ & 0.005 & 0.034 & - & 0.040 & - & - & 0.035 & 0.042 & & & 0,024 & 0,025 \\
\hline$\Sigma$ cations & 4.001 & 4.012 & 3.993 & 4.008 & 3.994 & 4.023 & 3.997 & 4.013 & 4,037 & 4,022 & 4,021 & 4,029 \\
\hline $\mathrm{Mg} / \mathrm{Fe}+\mathrm{Mg}$ & 0.144 & 0.195 & 0.078 & 0.113 & 0.148 & 0.216 & 0.066 & 0.099 & 0,449 & 0.493 & 0,583 & 0,597 \\
\hline $\mathbf{X}_{\text {wo }}$ & 12,6 & 10,6 & 7,5 & 6,6 & 14,1 & 12.0 & 6,4 & 5,4 & 3,4 & 1,7 & 40,3 & 42,3 \\
\hline $\mathbf{X}_{\mathrm{en}}$ & 79,4 & 46,1 & 92,2 & 53.0 & 83,9 & 44,8 & 93,2 & 51,1 & 44,9 & 49,6 & 33,4 & 36,4 \\
\hline $\mathbf{X}_{f s}$ & 8 & 43,3 & 0,3 & 40,4 & 2.0 & 43,2 & 0,4 & 43,5 & 51,7 & 48,7 & 26,2 & 21,3 \\
\hline $\mathbf{T}\left({ }^{0} \mathbf{C}\right)^{1}$ & \multicolumn{2}{|c|}{796} & \multicolumn{2}{|c|}{833} & \multicolumn{2}{|c|}{805} & \multicolumn{2}{|c|}{786} & \multirow{2}{*}{\multicolumn{4}{|c|}{$800-850^{\circ} \mathrm{C}^{*}$}} \\
\hline $\mathbf{T}\left({ }^{\circ} \mathbf{C}\right)^{2}$ & \multicolumn{2}{|c|}{823} & \multicolumn{2}{|c|}{843} & & & \multicolumn{2}{|c|}{802} & & & & \\
\hline
\end{tabular}

$\mathrm{T}^{1}$ - thermometry of Wood and Banno (1973); $\mathrm{T}^{2}$ - thermometry of Wells (1977)

AC //16 - mafic enderbite; AC 6/17, AC 6/14 and AC 13/15 - chamockite suite; AC 89 - mafic granulite; * estimates from lyer et al. (1996).

south of Guaxupé, roughly coincide with the pyroxenes from a mafic granulite of this study, occupying the centre of the pyroxene quadrilateral, but are not shown. The rim and core analyses of the pyroxenes from the mafic granulite, AC 89, possibly represent primary pyroxenes (core) equilibrated in granulite facies (rim - in the orthopyroxene this is represented by symplectite formation), but in the charnockitic gneisses there is no trace of any primary pyroxenes. As we shall see further on, the pyroxenes appear to be completely equilibrated in granulite facies, and their exsolution is a result of subsequent cooling.

\section{TEMPERATURE ESTIMATES AND P-T PATH}

From the São José do Rio Pardo area south of Guaxupé, Oliveira and Hypolito (1978) correlated pyroxene compositions to whole rock compositions, and the iron-rich composition of the host rocks is possibly one of the reasons for the pyroxenes being iron-rich as well. In the usual $K D$ plot the pyroxenes lie along a smooth curve with an average value of 0.65 , close to the value reported by the above authors. This value is near the limit for metamorphic pyroxenes (see e.g. Kretz, 1961; Sen and Manna, 1976), and attests to their equilibration under granulite facies conditions (Fig. 4).

Temperature estimates based on the method of Wood and Banno (1973) yield a range of $786^{\circ}$ to $833^{\circ} \mathrm{C}$, with an average around $809^{\circ} \mathrm{C}$, whereas the method of Wells (1977) gives higher temperatures. On the other hand, sample AC 89 also gave higher temperatures (lyer et al , 1996), possibly due to its higher $\mathrm{Mg} / \mathrm{Fe}$ ratio. For the sake of comparison with pyroxenes from this high-grade terrain for which analyses already exist, the Wood and Banno (1973) method is preferred, and temperatures obtained by Oliveira and Hypolito (1978) and Santos (1987) are compared with our results. The first authors reported values of $840 \pm 40^{\circ} \mathrm{C}$, while the average of the latter author is $825^{\circ} \mathrm{C}$.In this respect it is interesting to note that, for mangerites from an area further to the south, Janasi (1995) reported high temperatures around $1000^{\circ} \mathrm{C}$ for an anhydrous mangerite magma, and a metamorphic overprint in the range $750-800^{\circ} \mathrm{C}$ for these rocks. Values obtained here, using the method of Wood and Banno (1973) are not significantly different and are close to, but somewhat lower than, the peak temperatures on the P-T path estimated by lyer et al. (1996) for which the upper and lower estimates are 8.5 $\mathrm{kb} / 850^{\circ} \mathrm{C}$ and $6.0 \mathrm{~kb} / 650^{\circ} \mathrm{C}$ respectively. The lower values possibly represent the position where the pyroxenes followed a cooling path on which further cooling resulted in the exsolution reported here.

If this is the case, then they should have cooled along an isothermal decompression (ITD) path established by lyer et al. (1996) for rocks from the same area, accompanied by a 


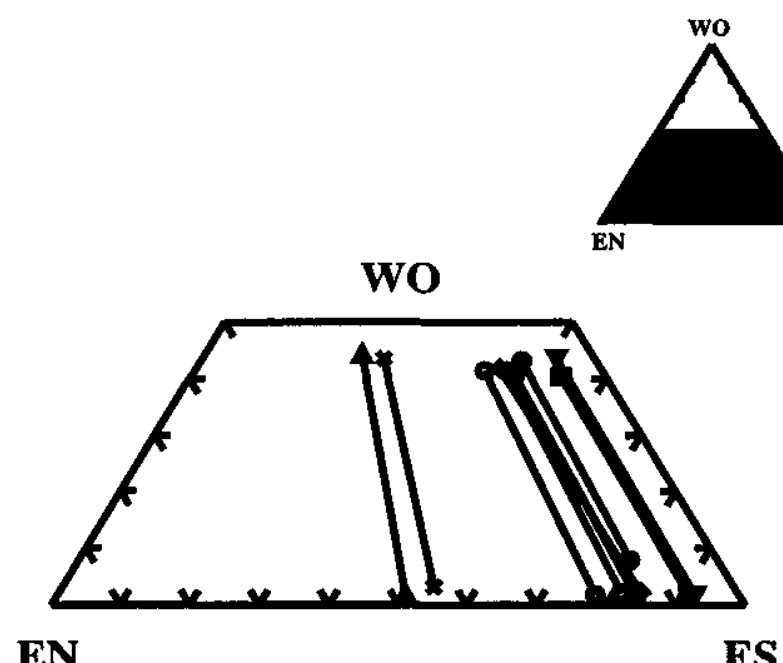

Figure 3 - Fe-rich pyroxenes from Guaxupé compared to pyroxenes of the charnockite-mangerite suite of Lofoten, Norway: open circles are from Lofoten, rest from Guaxupé $x$ and upright triangles are core and rim compositions from a mafic granulite.

Figura 3 - Piroxênios ricos em ferro de Guaxupé comparados com piroxênios da suíte charnockito-mangerítica de Lofoten, Noruega: círculos vazios para Lofoten e o restante para Guaxupé - $\mathrm{x}$ e triangulos verticals representam respectivamente composições de centra e bordos para granulitos máficos.

decrease in temperature. This path corresponds to the uplift of the Guaxupé nappe. Petrographic evidence for the ITD comes from breakdown of garnets in mafic granulite (Choudhuri et al. , 1995), and this is apparentely accompanied by temperature decrease as well. Garnet breakdown and the formation of orthopyroxene-plagioclase symplectite, evidently due to decompression, were mentioned previously by Santos (1987). This means that the pyroxenes probably followed a P-T path from $8.5 \mathrm{~kb}-850^{\circ} \mathrm{C}$ to $6.0 \mathrm{~kb}-650^{\circ} \mathrm{C}$ (maximum and minimum values from lyer et al , 1996) and exsolved on cooling. The lower temperature end could not be determined

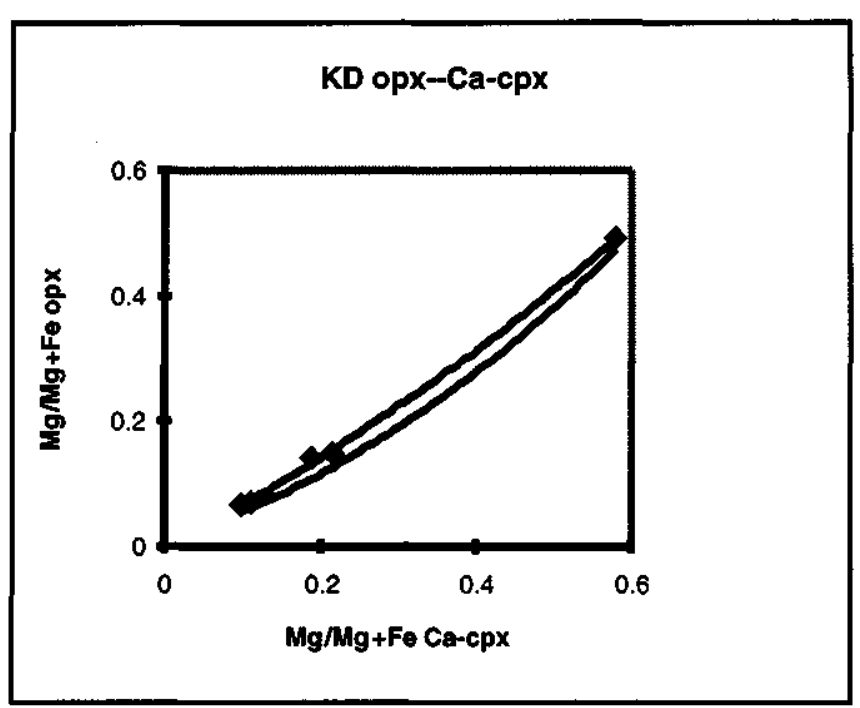

Figure 4 - Mg-Fe distribution for coexisting calcic clinopyroxene and orthopyroxene - KD $=0.65$. The second curve without points represents pyroxenes from Sen and Manna (1976), for which the $K D=0.55$.

Figura 4 - Distribuição de Fe-Mg para clinopirogênio cálcico e ortopiroxênio coexistentes - $\mathrm{KD}=0,65$. A segunda curva sem pontos representa piroxênios de Sen \& Manna (1976), para os quais o $\mathrm{KD}=0,55$.

for the pyroxenes, however, owing to the very fine scale of the exsolution that hampers analysis at the moment.

Acknowledgements We dedicate this contribution to the memory of Mario Figueiredo whose dynamism and cheerful nature will be remembered by all of us. His contributions in the field of petrology always stimulated those working in high-grade terrains.We thank Prof. Dr. J. Touret for the pyroxene analyses; A.C. is grateful to $\mathrm{CNPq}$ for financial support.

\section{REFERENCES}

BHATTACHARYA, A.; SEN, S.K. 1986 . Granulite metamorphism, fluid buffering, and dehydration melting in the Madras charnockites and metapelites. J. Petrology, 27, 1119-1141.

BOHLEN, S.R. ; ESSENE, E.J. 1978. Igneous pyroxenes from metamorphosed anorthosite massifs. Contrib. Mineral.Petrol., 65,433-422.

CAVALCANTE, J.C.; CUNHA, H.C. das; CHIEREGATTI, L.A.; KAEFFER, L.Q.; ROCHA, J.M. da; DAITX, E.G.; COUTINHO, M.G. da N.: YAMAMMOTO, K.; DRUMOND, J.B.V.; ROSA, D.B.; RAMALHO, R. 1979. Projeto Sapucaí - Relatório Final. Convênio DNPM/ CPRM, Brasília, 299p.

CHOUDHURI, A.; SILVA, D; NOGUEIRAJ R. ; SZABÓ, G. 1995. Granulite facies rocks from Guaxupé, MG: gneiss-fluid sequences and P-T conditions. Geonomos, 3(2): 43-49

DEER, W.A., HOWIE, R.A. ; ZUSSMAN, J. 1992. An introduction to the rock forming minerals - 2nd Edition. Longman Scientific and Technical. Essex, England.

IYER, S.S.; CHOUDHURI, A.; PATTISON, D.R.M. ; DE PAOLI, G.R. 1966. Petrology and geochemistry of the Neoproterozpic Guaxupé granulite facies terrain, southeastern Brazil. Precambrian Res., 77, $23-40$.

JANASI, V.A. 1995. Neoproterozoic mangerite- "rapakivi" granite magmatism in southeastern Brazil: The São Pedro de Caldas Massif. Symp. Rapakivi Granites and Related Rocks, Belém, Brazil. Abstracts, 44-45.

KRETZ, R. 1961. Some applications of thermodynamics to coexisting minerals of variable compositions. Examples: orthopyroxene-clinopyroxene and orthopyroxene-garnet. Jour. Geol., 69.361-387.

OLIVEIRA, M.A.F.de ; HYPOLITO, R. 1978. Ortopiroxênios e clinopiroxênios coexistentes nos granulitos de São José do Rio Pardo, SP. Rev. Bras. Geoc. 8:249-261.
OLLILA, P.W., JAFFE, H.W. ; JAFFE, E. 1988. Pyroxene exsolution: An indicator of high-pressure igneous crystallization of pyroxene-bearing quartz syenites from the High Peaks region of the Adirondack Mountains. Amer. Mineral.73: 261-273.

ORMAASEN, D.E. 1977. Petrology of the Hopen mangerite-charnockite intrusion, Lofoten, north Norway. Lithos, 10: 291-310.

SANDIFORD, M.; POWELL, R. 1986. Pyroxene exsolution in granulites from Fyfe Hills, Enderby Land, Antarctica: evidence for $1000^{\circ} \mathrm{C}$ metamorphic temperatures in Archean continental crust. Amer. Mineral. 71: 946-954.

SANTOS, A.. M. dos. 1987. Caracterização petrológica dos granulitos básicos da folha de Guaranésia (MG). M.Sc. thesis.Univ.São Paulo, 160 pp. (unpubl.).

SCHOBBENHAUS, $F^{\circ} C$; CAMPOS, P de A. DERZE, G.R.; ASMUS, H.E. 1984. Geologia do Brasil. DNPM, Brasília, 501 p.

SEN, S.K ; MANNA, S.S. 1976. Patterns of cation fractionation among pyroxenes, hornblende and garnet in the basic granulites of Saltora, West Bengal. Indian Jour. Earth Sci., 3: 117-128.

WELLS, R.A. 1977. Pyroxene thermometry in simple and complex systems. Contrib. Mineral. Petrol., 62,129-139.

WOOD, B.J.; BANNO, S. 1973. Garnet-orthopyroxene and orthopyroxeneclinopyroxene relationships in simple and complex systems. Contrib. Mineral. Petrol., 42 : 109-124. 